\title{
JPEB
}

Jurnal Penelitian Ekonomi dan Bisnis, 2 (2), 2017, Hal : 58 - 67

http://www.jpeb.dinus.ac.id

\section{RASIO KEUANGAN DAN PREDIKSI FINANCIAL DISTRESS}

\author{
1 \\ 1,2 \\ Jenny Pratiwi Assaji dan Zaky Machmuddah \\ Program Studi Akuntansi, Fakultas Ekonomi dan Bisnis, Universitas Dian Nuswantoro \\ Jalan Nakula I No. 5-11 Semarang, Indonesia \\ *Corresponding Author: zaky.machmuddah@dsn.dinus.ac.id
}

Diterima : April 2017; Direvisi : Juni 2017; Dipublikasikan : September 2017

\begin{abstract}
The purpose of this research is to understand the effect of financial ratios in predicting the possibility of financial distress on companies listed on Sri Kehati index in a row of 2009-2016. This study uses the financial ratios proxied by return on assets, return on capital, net profit margin, $P$ / E ratio, and asset turnover as independent variables. Meanwhile, the financial distress proxied by Z-score is a dependent variable. The population of this study is all companies listed on the index of Sri Kehati in 2009-2016 and listed on the Indonesia Stock Exchange. The sample of this study took nine companies with purposive sampling method and the study period is for eight years in a row (2009-2016). Logistic regression method used in this research. The results show that ROA, ROE and PER have a significant effect on financial distress. Meanwhile, NPM and ATO have no significant effect on financial distress.
\end{abstract}

Keywords: Financial Ratio; Financial Distress

\begin{abstract}
ABSTRAK
Tujuan dari penelitian ini adalah untuk memahami pengaruh rasio keuangan dalam memprediksi kemungkinan terjadinya financial distress pada perusahaan yang terdaftar pada indeks Sri Kehati secara berturut-turut tahun 2009-2016. Penelitian ini menggunakan rasio keuangan yang diproksikan dengan pengembalian atas aset, pengembalian atas modal, marjin laba bersih, rasio P/E, dan perputaran aset sebagai variabel bebas. Sedangkan, financial distress yang diproksikan dengan Z-score merupakan variabel terikat. Populasi penelitian ini adalah seluruh perusahaan yang terdaftar pada indeks Sri Kehati tahun 2009-2016 dan tercatat pada Bursa Efek Indonesia. Sampel penelitian ini mengambil sembilan perusahaan dengan metode purposive sampling dan periode penelitian adalah selama delapan tahun berturut-turut (2009-2016). Metode penelitian ini menggnakan regresi logistik. Hasil penelitian menunjukkan bahwa ROA, ROE dan PER memberikan pengaruh yang sifnifikan terhadap financial distress. Sedangkan, NPM dan ATO tidak memberikan pengaruh yang signifikan terhadap financial distress.
\end{abstract}

Kata Kunci: Rasio Keuangan; Financial Distress 



\section{PENDAHULUAN}

Permasalahan financial distress terjadi pada PT.Century, tbk. yang berawal dari insiden kalah kliring pada tahun 2008 yang menyebabkan munculnya keputusan penyuntikan dana dari Lembaga Penjamin Simpanan (LPS) yang membawa Bank Century mengalami permasalahan financial distress yang semakin parah. Permasalahan financial distress ini semakin parah karena terjadinya rasio keuangan yang tidak berada pada nilai positif yang dianggap memberikan laba. Nasabah mengalami kendala saat melakukan penarikan dana karena Bank Century tidak memiliki kemampuan melikuidasi dana yang ada. Sejak PT. Century, tbk. dijadikan, Bank Century yang berasal dari hasil merger tiga bank ini memang sudah dalam kondisi financial distress dimana rasio modal mengalami penurunan hingga sampai pada angka negatif 83,6\% disertai kekurangan modal sebesar Rp 2,67 triliun rupiah (Pikiran Rakyat, 2010).

Berdasarkan fenomena di atas, seharusnya jauh sebelum perusahaan menunjukkan tanda-tanda akan mengalami financial distress perusahaan wajib untuk terus mengamati kondisi dari waktu ke waktu karena kasus Bank Century adalah permasalahan yang semakin menyebar sampai tingkat kompleksitas yang tinggi karena situasi financial distress tidak dicegah sejak awal melalui pengamatan tiap-tiap rasio keuangan yang ada sehingga pencegahan dilakukan beriringan dengan berjalannya operasional Bank Century.

Situasi dimana perusahaan sedang mengalami kesulitan keuangan dapat dinilai dan dilihat melalui laporan keuangan yang tercatat pada indeks-indeks tertentu. Financial distress adalah tahap penurunan situasi pendanaan yang terjadi sebelum perusahaan dinyatakan bangkrut atau mengalami kebankrutan maupun likuidasi. Kesulitan keuangan dapat dimulai dari kesulitan likuidasi dalam jangka pendek yang dianggap sebagai kondisi financial distress ringan hingga ada pada pernyataan kebangkrutan yang dianggap sebagai financial distress terberat.

Penyebab financial distress adalah ketidakmampuan perusahaan dalam hal pengelolaan atau pertahanan stabilitas kinerja keuangan perusahaan yang berawal dari ketidakberhasilannya dalam kegiatan promosi produk sehingga terjadi penurunan penjualan yang mengakibatkan pendapatan yang semakin menurun dan penjualan yang tidak maksimal. Hal tersebut memicu perusahaan mengalami kerugian dalam hal operasional selama kurun waktu berjalan saat itu.

Financial distress selalu terjadi sebelum kebangkrutan dialami perusahaan. Banyak hal yang dilakukan oleh perusahaan selama terjadi financial distress seperti perubahan yang signifikan terhadap aset, laba bersih dan laba per saham. Hal ini dilakukan demi menjaga perusahaan untuk tetap berjalan dan kembali pada kondisi keuangan yang normal.

Pada hakikatnya, laporan keuangan menjadi acuan bagi pihak internal maupun eksternal perusahaan dalam menilai kinerja keuangan perusahaan pada kurun waktu tertentu. Analisa terhadap laporan keuangan dapat diteliti menggunakan rasio-rasio keuangan yang menjadi tolok ukur kinerja keuangan perusahaan termasuk kemungkinan terjadinya financial distress atau bahkan kebangkrutan.

Ditemukannya kondisi kesulitan pada operasi dan keuangan perusahaan menjadi subjek yang sangat rentan terhadap analisis rasio keuangan (Altman, 2000). Hal ini menunjukkan bahwa adanya keterkaitan erat antara rasio keuangan terhadap prediksi financial distress. Analisis rasio keuangan memberikan sebuah pola keterkaitan suatu pos atau akun tertentu satu sama lain di dalam laporan keuangan. Artinya, penggambaran rasio keuangan ini menunjukkan situasi perusahaan melalui laporan posisi keuangan dengan perbandingannya yang kemudian diperhitungkan dan diperbandingan dengan angka rasio yang disepakati sebagai standar.

Pemahaman rasio keuangan terhadap interpretasi rasio wajib dipahami secara hati-hati karena kuatnya keterkaitan faktor yang mempengaruhi pembilang terhadap faktor yang 
mempengaruhi penyebut. Artinya, dalam memperhitungkan keterkaitan rasio keuangan terhadap prediksi financial distress harus benar-benar memperhatikan variabel yang terkait terhadap faktor pendorong terjadinya financial distress karena sekian banyak rasio tidak selalu berpengaruh signifikan terhadap terjadinya financial distress (Subramanyam, 2010).

Penelitian ini terfokus pada beberapa dari sekian rasio keuangan yang ada. Analisis kredit tidak diperhitungkan dalam penelitian ini karena beberapa peneliti telah menguji bahwa analisis kredit tidak berdampak terhadap prediksi financial distress secara signifikan. Analisis profitabilitas yang diperhitungkan dalam penelitian ini adalah pengembalian atas asset atau return on asset (ROA), return on equity (ROE), net profit margin (NPM), pricelearning ratio (PER), dan asset turnover.

Penelitian dengan rasio keuangan ini menjadikan analisis laporan keuangan perusahaan sebagai acuan jalan keluar bagi perusahaan yang mengalami financial distress oleh banyak faktor dengan penggambaran gejala-gejala yang ada pada perusahaan (Prastowo, 2011). Rasio ini mampu menyingkap adanya keterkaitan yang menjadikan dasar komparatif akan kondisi atau kecenderungan perusahaan yang belum terdeteksi.

Penelitian dengan rasio keuangan yang melibatkan rasio likuiditas ataupun rasio kredit cenderung memberikan jawaban yang tidak signifikan terhadap prediksi financial distress dibuktikan oleh Prastowo, 2011. Hasil penelitiannya membuktikan bahwa rasio likuiditas memberikan pengaruh bila dikaitkan dengan adanya rasio yang lain yang menunjukkan adanya situasi financial distress tidak serta merta berasal dari unsur rasio likuiditas seutuhnya.

Telah dilakukan berbagai penelitian mengenai financial distress yang mengkaji manfaat dari rasio keuangan sebagai alat deteksi perusahaan yang tepat. Salah satu penelitian yang terkenal dilakukan oleh Altman (2000) yaitu peneliti awal yang telah menelaah pemanfaat analisis rasio keuangan sebagai pendeteksi situasi financial distress. Model penelitian Altman (2000) yang dikenal oleh banyak peneliti yaitu Z-Score yaitu penentuan score dari hasil perhitungan standar akun - akun keuangan yang kemungkinan mengalami kebangkrutan.

Literatur yang memberi gambaran terhadap model prediksi kesulitan keuangan semakin banyak diterbitkan, namun penelitian yang secara mutlak menampilkan prediksi tentang financial distress tidaklah marak. Hal ini disebabkan karena sulitnya mendefinisikan kemunculan financial distress di masing-masing perusahaan yang berbeda-beda dalam hal kemampuan perusahaan baik dalam memenuhi kewajiban, memanfaatkan modal dan aset, kemampuan likuidasi dan masih banyak lagi. Itulah mengapa banyak penelitian yang memiliki perbedaan kesimpulan dengan penelitian lainnya. Hal ini menunjukkan bahwa suatu variabel tidak akan menjamin kondisi keuangan perusahaan yang satu sama dengan perusahaan lainnya.

ROA menjadi variabel yang menunjukkan kinerja keuangan sehingga dijadikan sebagai alat deteksi terhadap situasi financial distress. Penelitian ini didukung dengan penelitian dari Mas'ud dan Srengga (2012) bahwa ROA berpengaruh negatif signifikan terhadap prediksi financial distress. Artinya, semakin kecil ROA maka semakin besar kemungkinan perusahaan mengalami financial distress. ROE dinyatakan berpengaruh signifikan terhadap terjadinya situasi financial distress pada perusahaan yang tercatat di BEI oleh Haq, dkk. (2013). Hasil yang berbeda dinyatakan oleh penelitian Nurcahyono dan Sudharma (2014) bahwa ROE tidak berpengaruh bagi financial distress.

Putra, dkk (2017), Christananda (2017), dan Haq (2013) membuktikan bahwa variabel NPM berpengaruh signifikan terhadap prediksi financial distress. PER yang tinggi menunjukkan situasi yang baik terhadap perusahaan dimana investor mengalami kepuasan terhadap pendapatan yang tinggi pula karena dividen lebih tinggi dan risiko saham rendah. Artinya, perusahaan jauh dari situasi financial distress. 
Rasio asset turnover (ATO) memberikan pengaruh yang signifikan terhadap situasi financial distress perusahaan berdasarkan penelitian yang telah dilakukan oleh Noviandri (2014). Tidak sejalan dengan Noviandri (2014), penelitian Abidin (2013) memberikan hasil yang berbeda bahwa ATO tidak memberikan pengaruh terhadap prediksi financial distresss.

Berdasarkan penelitian-penelitian terdahulu yang ditemukan dan telah dijelaskan di atas didapatkan berbagai research gap terhadap faktor-faktor yang berpengaruh terhadap prediksi financial distress. Penelitian Saleh dan Sudiyatno (2013) sebagai acuan penelitian ini, namun terdapat perbedaan antara penelitian ini dengan penelitian dari Saleh dan Sudiyatno (2013). Perusahaan yang terdaftar dalam indeks Sri Kehati pada tahun 2009-2016 dijadikan sebagai obyek penelitian.

Dari penjelasan diatas maka dapat ditarik pertanyaan penelitian sebagai berikut: (1) apakah rasio profitabilitas berpengaruh terhadap kondisi financial distress pada perusahaan yang terdaftar pada indeks Sri Kehati ?, (2) apakah price to earning ratio berpengaruh terhadap kondisi financial distress pada perusahaan yang terdaftar pada indeks Sri Kehati ?, (3) apakah asset turnover berpengaruh terhadap kondisi financial distress pada perusahaan yang terdaftar pada indeks Sri Kehati ?.

\section{TINJAUAN PUSTAKA \\ Teori Sinyal}

Teori sinyal menurut Arkelof (1970) adalah situasi dimana penjual memiliki informasi lebih daripada pembeli. Adanya sinyal dari penjual mengenai informasi terkait produk menyebabkan pembeli mengetahui lebih jauh informasi mengenai produk yang akan dikonsumsi sehingga penilaian terhadap kualitas produk dapat dilihat oleh pembeli secara lebih akurat. Pada dasarnya, teori sinyal menyatakan bahwa perusahaan menjadi pihak yang terdorong untuk menyajikan informasi seputar laporan keuangan terhadap pihak-pihak pemangku kepentingan sehingga situasi perusahaan dapat diketahui. Harapannya adalah supaya pihak-pihak pemangku kepentingan dapat memberikan penilaian secara tepat kepada perusahaan.

\section{Pengembangan Hipotesis}

Semakin ROA menunjukkan angka positif sejumlah aset yang saat ini dimiliki perusahaan maka perusahaan mampu mempertahankan kondisi dan situasinya untuk tetap memperoleh laba. Pernyataan di atas menunjukkan bahwa indikator ROA yang disajikan oleh perusahaan memberikan informasi kepada pemangku kepentingan dalam mengambil keputusan terhadap kemungkinan terjadinya financial distress. Artinya bahwa perusahaan yang memiliki ROA yang semakin positif maka perusahaan akan semakin kecil berada dalam situasi financial distress. Penelitian Nurcahyono dan Sudharma (2014), Saleh dan Sudiyatno (2013), serta Marwati (2012) memberikan hasil bahwa apabila ROA perusahaan semakin tinggi atau keuntungan perusahaan semakin meningkat atas aset yang dimiliki, maka akan semakin rendah munculnya kemungkinan perusahaan mengalami financial distress.

$\mathrm{H}_{1}$ : Return on Assets berpengaruh terhadap prediksi financial distress perusahaan.

ROE yang menunjukkan angka positif adalah baik, dimana perusahaan dianggap telah menggunakan modal/ekuitas secara efisien dan efektif karena laba diperoleh saat modal diperlakukan dengan baik untuk meningkatkan nilai saham, hal tersebut merupakan sinyal yang diberikan perusahaan untuk para stakeholder mengambil keputusan. Oleh karena itu, perusahaan yang ROEnya menunjukkan angka positif semakin besar, maka akan semakin kecil kemungkinan perusahaan mengalami financial distress. Menurut penelitian Widati dan Pratama (2014), Haq, dkk (2013), serta Saleh dan Sudiyatno (2013), ROE memberikan pengaruh terhadap adanya kemungkinan kesulitan keuangan. 
$\mathrm{H}_{2}$ : Return on Equity berpengaruh terhadap prediksi financial distress perusahaan.

NPM menunjukkan bagaimana perusahaan dalam periode tertentu menghasilkan laba bersih perusahaan setelah dikurangi pembayaran pajak. Semakin besar NPM perusahaan menunjukkan tingkat kepercayaan investor yang lebih tinggi karena perusahaan dianggap sedang berada dalam situasi yang produktif, sehingga semakin menunjukkan bahwa perusahaan semakin kecil berada dalam kemungkinan financial distress. Hal tersebut dapat dijadikan informasi bagi para pemangku kepentingan dalam pengambilan keputusan investasi. Putra, dkk (2017), Christananda (2017), dan Haq (2013) membuktikan bahwa NPM memberikan pengaruh terhadap prediksi financial distress yang terjadi pada perusahaan.

$\mathrm{H}_{3}$ : Net Profit Margin berpengaruh terhadap prediksi financial distress perusahaan.

PER merupakan rasio pembanding antara harga saham yang dikeluarkan perusahaan dengan laba bersih yang diperoleh perusahaan. Artinya, semakin besar PER menunjukkan bahwa transaksi pasar modal berlangsung produktif sehingga kemungkinan perusahaan mengalami financial distress semakin kecil. Dengan demikian, PER menjadi sinyal dalam pengambilan keputusan yang diberikan perusahaan terhadap para pengguna informasi terhadap kondisi financial distress perusahaan. Choirina (2015) dan Brigham dan Houston (2013), rasio PER akan semakin meningkat apabila perusahaan mengalami perkembangan keuntungan yang baik sehingga risiko kebangkrutan cenderung merendah.

$\mathrm{H}_{4}$ : Price to Earning Ratio berpengaruh terhadap prediksi financial distress perusahaan.

ATO menjadi rasio untuk melihat jumlah aset yang dimanfaatkan oleh perusahaan selama jangka periode tertentu dibandingkan jumlah aset yang diperoleh/dimiliki perusahaan untuk mengukur efisiensi penggunaan aset atas berapa kali perputaran yang telah terjadi selama kurun periode tertentu. Artinya, semakin baik pemanfaatan aset perusahaan atas anggapan bahwa perusahaan melakukan efisiensi terhadap perlakuan asetnya menunjukkan bahwa perusahaan semakin kecil mengalami kemungkinan terjadinya financial distress. Hal ini memperjelas bahwa perusahaan memberikan sinyal dalam pengambilan keputusan mengenai situasi financial distress melalui nilai dari ATO perusahaan. Yudiawati dan Indriani (2016) dan Noviandri (2014) menjelaskan bahwa perputaran aset memberikan pengaruh yang signifikan terhadap prediksi financial distress.

H5: Assets Turnover berpengaruh terhadap prediksi financial distress perusahaan.

\section{METODE PENELITIAN}

Variabel dependen pada penelitian ini adalah financial distress. Variabel financial distress dalam perhitungannya adalah variabel dummy, variabel dummy hanya memiliki nilai 0 atau 1. Apabila nilai dari financial distress dengan rumus $Z$ score menghasilkan nilai lebih besar dari 2,9 maka nilai 0 , sedangkan apabila nilai lebih kecil dari 2,9 maka nilainya 1 . Tabel variabel dummy di atas dijelaskan pada tabel sebagai berikut:

Tabel 1. Kriteria Dummy

\begin{tabular}{lll}
\hline Kategori & Non FD & FD \\
\hline & $(0)$ & $(1)$ \\
Zona Distress & $<1,23$ & \\
Zona Abu-abu & $2,9<$ Z Score $>1,23$ & $>2,9$ \\
Zona Aman & & \\
\hline
\end{tabular}

Variabel independen dalam penelitian ini adalah rasio keuangan yang meliputi ROA, ROE, NPM, PER dan ATO. Adapun pengukurannya tersaji dalam tabel 2. 
Tabel 2. Variabel Penelitian

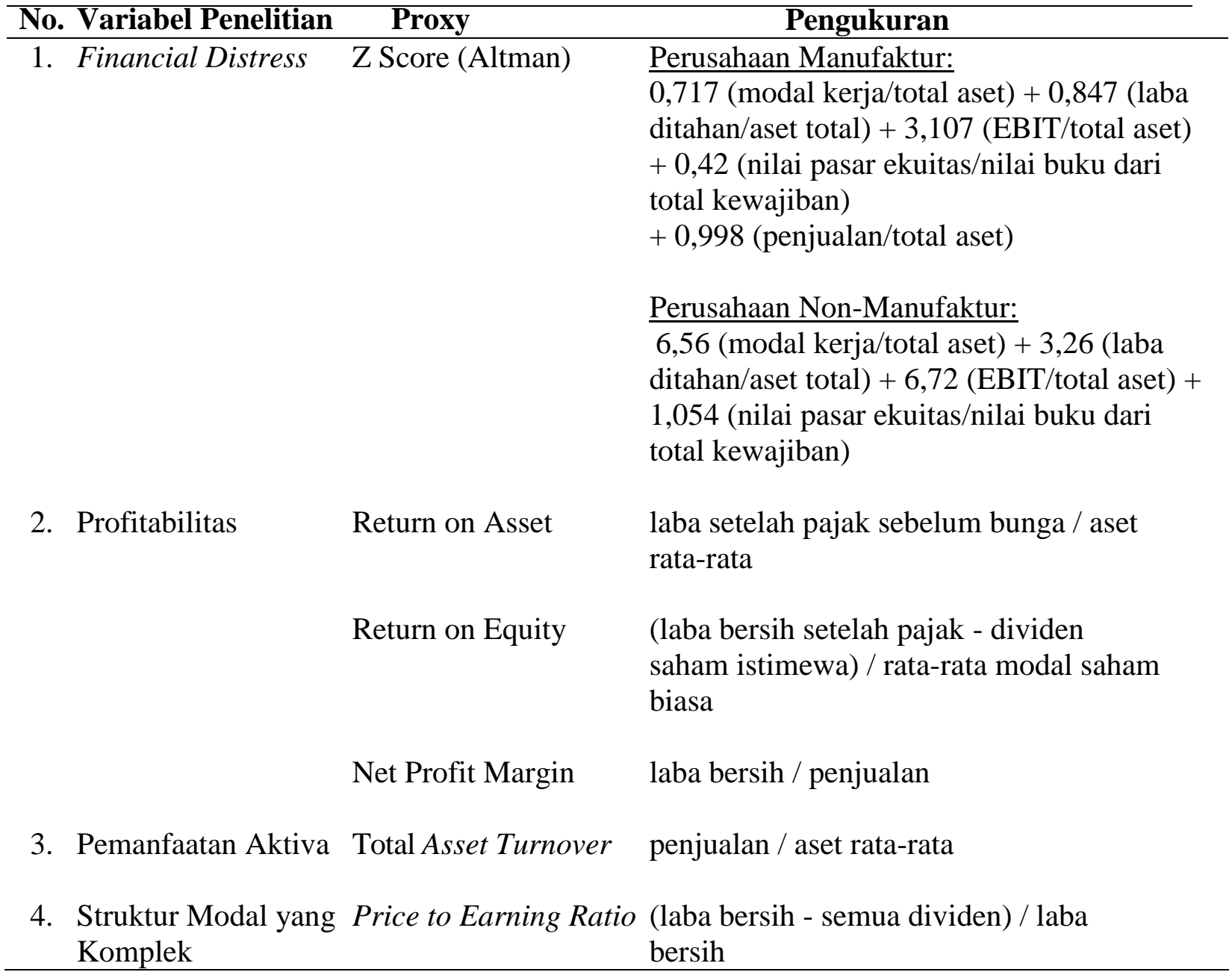

Populasi dari penelitian ini adalah seluruh perusahaan yang tercatat di Indeks Sri Kehati pada Bursa Efek Indonesia untuk tahun 2009-2016. Pengambilan sampel dilakukan dengan metode purposive sampling yaitu pengambilan sampel dengan kriteria tertentu menurut data yang diperlukan. Kriteria sampel yang diperlukan untuk sampel ini adalah sebagai berikut : (1) memiliki data terkait variabel yang dibutuhkan, (2) perusahaan non keuangan, dan (3) perusahaan yang menggunakan kurs rupiah.

Model regresi logistik (logistic regression) digunakan untuk pengolahan data. Model regresi logistik melakukan berbagai uji seperti pengujian kelayakan model (goodness of fit test), penilaian model fit (overall model fit), koefisien determinasi dan uji regresi. Analisis regresi pada dasarnya merupakan suatu studi untuk mengetahui pengaruh satu atau lebih variabel independen terhadap satu variabel dependen. Hubungan antara ROA, ROE, NPM, PER dan ATO dengan financial distress. Model persamaan regresi dalam penelitian ini dinyatakan sebagai berikut:

$$
\begin{aligned}
& \mathrm{Y}=\beta_{0}+\beta_{1} \mathrm{X}_{1}+\beta_{2} \mathrm{X}_{2}+\beta_{3} \mathrm{X}_{3}+\beta_{4} \mathrm{X}_{4}+\beta_{5} \mathrm{X}_{5}+€ \\
& \text { Keterangan : } \\
& \mathrm{Y} \quad=\text { Financial Distress } \\
& \mathrm{B} \quad=\text { Koefisien regresi } \\
& \mathrm{X}_{1} \quad=\text { ROA } \\
& \mathrm{X}_{2} \quad=\mathrm{ROE} \\
& \mathrm{X}_{3} \quad=\mathrm{NPM} \\
& \mathrm{X}_{4} \quad=\text { PER }
\end{aligned}
$$




$$
\begin{array}{ll}
\mathrm{X}_{5} & =\mathrm{ATO} \\
\varepsilon & =\text { Residual error }
\end{array}
$$

\section{HASIL DAN PEMBAHASAN}

\section{Pengaruh ROA terhadap prediksi Financial Distress}

Hasil pengujian data menunjukkan bahwa ROA berpengaruh signifikan terhadap prediksi financial distress. Hal ini dapat dilihat dari tabel 3, nilai koefisien regresi pada variabel ROA adalah sebesar -63,295. Besaran tersebut adalah mengikuti arah negatif yang memberikan makna bahwa apabila variabel ROA mengalami peningkatan dalam satu satuan maka prediksi terhadap financial distress adalah -63,295 dengan situasi dimana variabel independen selain ROA adalah tetap besaran nilainya.

Berdasarkan teori sinyal yang ada, perusahaan memberikan dorongan dalam menyajikan informasi untuk pengambilan keputusan seputar laporan keuangan terhadap pihak internal maupun pihak eksternal. Kecenderungan dorongan yang diberikan perusahaan tersebut terjadi dikarenakan adanya informasi yang tidak seimbang antara pihak internal dengan pihak eksternal dimana pihak internal memiliki informasi seputar keuangan perusahaan yang lebih lengkap sehingga lebih mudah untuk memprediksi financial distress daripada pihak eksternal yang memprediksi dari hasil laporan keuangan yang telah dipublikasi yang memungkinkan situasi riil tidak sama dengan hasil dari laporan keuangan.

Hal inilah yang menjadi sinyal perusahaan untuk mencegah terjadinya kemungkinan kesulitan keuangan melalui pemantauan jumlah ROA pada tiap periode untuk memprediksi situasi keuangan yang diharapkan. Perusahaan perlu mempertimbangkan upaya-upaya dalam mengatasi kemungkinan terjadinya financial distress manakala terjadi peningkatan ataupun penurunan ROA perusahaan untuk dapat mengantisipasi resiko perusahaan dalam hal keputusan menjual atau menjaga aset perusahaan sesuai dengan hasil riil laporan keuangan. Penelitian ini mendukung penelitian-penelitian terdahulu yang telah dilakukan oleh Saleh dan Sudiyatno (2013) serta Marwati (2012).

\section{Pengaruh ROE terhadap prediksi Financial Distress}

Pengujian data yang dilakukan dengan model regresi logistik menampilkan nilai koefisien positif 4,299 dengan tingkat signifikansi 0,465 yang lebih besar dari 5\%. Berarti bahwa ROE tidak berpengaruh terhadap prediksi financial distress. Hasil penelitian ini menjelaskan bahwa adanya peningkatan atau penurunan pada ROE perusahaan tidak mempengaruhi kemampuan perusahaan dalam menghindari probabilitas terjadinya financial distress.

Penelitian ini memberikan kejelasan bahwa ROE tidak dapat menjadi sinyal bagi perusahaan karena pergerakan dari ROE tidak mempengaruhi prediksi kemungkinan terjadinya financial distress perusahaan. ROE hanya dapat menampilkan kemampuan perusahaan dalam hal pengembalian modal secara efektif namun nilai ROE tidak berkontribusi dalam pergerakan prediksi financial distress di perusahaan. Temuan penelitian sejalan dengan hasil penelitian dari Nurcahyono dan Sudharma (2014).

Tabel 3. Hasil Pengujian Hipotesis

\begin{tabular}{llll}
\hline & & \multicolumn{1}{c}{ B } & \multicolumn{1}{c}{ Sig. } \\
\hline Step 1a & log_X1 & $-63,295$ & 0,011 \\
& X2 & 4,299 & 0,465 \\
& log_X3 & 54,899 & 0,027 \\
& X4 & $-0,244$ & 0,042 \\
& log_X5 & 57,610 & 0,019 \\
& Constant & $-6,933$ & 0,049 \\
\hline
\end{tabular}




\section{Pengaruh NPM terhadap prediksi Financial Distress}

Tabel 3 menyajikan hasil pengujian data yang dilakukan dengan model regresi logistik, terlihat bahwa nilai koefisien positif 54,899 dengan tingkat signifikansi 0,027 yang lebih kecil dari 5\%. Hasil uji menjelaskan bahwa variabel NPM berpengaruh terhadap prediksi financial distress. Rasio NPM menjelaskan mengenai marjin laba bersih yang diperoleh perusahaan selama periode tertentu.

Hal ini selaras dengan hipotesis dari peneliti bahwa NPM berpengaruh terhadap prediksi financial distress dimana NPM mewakili kondisi perusahaan dalam memperoleh laba bersih sehingga kemungkinan adanya situasi kesulitan keuangan sangat kecil karena perusahaan memiliki kemampuan yang baik dalam menghasilkan laba bersih. Dengan demikian, pihak internal serta eksternal memiliki anggapan bahwa perusahaan dianggap mampu dalam mengawasi situasi keuangannya selama periode tertentu. NPM menyajikan pendapatan perusahaan melalui penjualan yang dilakukan sedangkan kondisi financial distress cenderung terkait dengan penjualan yang secara bersamaan dikalkulasikan dengan sumber pendanaan eksternal (Christananda, 2017).

Keputusan untuk menjual atau mempertahankan aset tetap mampu mewakili perusahaan berada dalam situasi aman dari financial distress. Artinya, hal tersebut menandakan bahwa adanya peningkatan atau penurunan NPM memberikan pengaruh terhadap prediksi financial distress. Berdasarkan teori sinyal yang memberikan pernyataan bahwa perusahaan memiliki kemampuan dalam memberikan sinyal dengan informasi yang disampaikan dari laporan keuangan perusahaan, NPM disebut sebagai sinyal perusahaan dikarenakan NPM mampu mewakili informasi perusahaan secara menyeluruh terhadap adanya situasi financial distress. Temuan penelitian ini sesuai dengan temuan penelitian dari Putra dkk (2017) dan Christananda (2017).

\section{Pengaruh PER terhadap prediksi Financial Distress}

Model regresi logistik dalam tabel 3 menampilkan nilai koefisien negatif 0,244 dengan tingkat signifikansi 0,042 yang lebih kecil dari 5\%. Hasil yang ditampilkan tersebut menunjukkan bahwa hipotesis keempat diterima yaitu PER berpengaruh terhadap prediksi financial distress.

PER mengindikasikan besarnya jumlah dimana investor bersedia membayar setiap rupiah atas pendapatan perusahaan yang diperoleh. Artinya, semakin tinggi nilai PER perusahaan maka semakin banyak investor yang hendak menanamkan sahamnya di perusahaan sebab perusahaan memiliki kemungkinan yang kecil untuk terjebak di situasi financial distress. Selain itu, keterkaitan dengan teori sinyal adalah kecenderungan ketimpangan informasi dimana pihak internal lebih memahami seluk beluk keuangan perusahaan justru mendorong pihak internal dalam memperhatikan nilai dari PER dikarenakan PER menjadi sinyal atau daya tarik perusahaan dalam meyakinkan pihak eksternal akan situasi keuangan perusahaan yang sedang dialami. PER memberikan sinyal bagi penggunanya yang apabila mengalami kenaikan atau penurunan maka akan mempengaruhi keputusan eksternal dalam menyokong sumber pendanaan perusahaan.

Adanya peningkatan atau penurunan PER mempengaruhi keputusan pihak eksternal dalam menanamkan saham perusahaan atau melanjutkan pendanaan perusahaan. PER menggambarkan perusahaan dalam situasi pertumbuhan ekonomi yang baik. Artinya, semakin tinggi nilai PER maka kondisi keuangan perusahaan adalah semakin baik atau bisa dikatakan bahwa perusahaan terhindar atau memiliki kemungkinan kecil untuk terjebak dalam situasi financial distress. Pernyataan ini mendukung penelitian-penelitian terdahulu oleh Choirina (2015), dan Zaki, et al. (2011). 


\section{Pengaruh ATO terhadap prediksi Financial Distress}

Nilai koefisien yang tersaji dalam tabel 3 , positif 57,610 dengan tingkat signifikansi 0,019 yang lebih kecil dari 5\%. Tampilkan tersebut menunjukkan hasil bahwa hipotesis diterima yaitu ATO berpengaruh terhadap prediksi financial distress. ATO menjelaskan bagaimana rasio berkaitan dengan perputaran aset mampu mengukur efektivitas pengelolaan perusahaan dalam hal aset. Hasil uji menunjukkan bahwa nilai signifikansi dari variabel ATO memiliki besaran 0,019 dimana angka signifikansi ini berada dalam batas signifikansi sebesar 0,05 yang diartikan bahwa variabel ATO memberikan pengaruh pada financial distress. Semakin efektif pengelolaan perusahaan yang ditunjukkan maka perusahaan dianggap mampu dalam mengatasi kesulitan keuangannya (Sudana, 2011).

ATO dianggap menjadi tolok ukur akan efektivitas perusahaan dalam mengelola keuangan terutama pada bagian aset. Semakin efektif pengelolaan perusahaan yang ditunjukkan maka perusahaan dianggap mampu dalam mengatasi kesulitan keuangannya (Sudana, 2011). ATO memberikan pengaruh yang besar terhadap jaminan situasi keuangan yang terjadi maupun kemampuan terhindar dari financial distress. Apabila dikaitkan dengan teori sinyal, ATO mampu menjadi sinyal bagi pihak internal selain manajer maupun pihak eksternal karena ATO memberikan pengaruh terhadap timbulnya financial distress (Noviandri, 2014). Hasil penelitian ini mendukung hasil dari penelitian-penelitian terdahulu yang dilakukan oleh Noviandri (2014).

\section{SIMPULAN}

Berdasarkan hasil analisis data mengenai pengaruh rasio keuangan sebagai variabel independen terhadap prediksi financial distress sebagai variabel dependen untuk indeks Sri Kehati tahun 2009-2016, diperoleh simpulan penelitian ROA, ROE dan PER memberikan pengaruh yang signifikan terhadap financial distress. Namun demikian, NPM dan ATO tidak memberikan pengaruh yang signifikan terhadap financial distress.

Penelitian ini memiliki beberapa keterbatasan yang dapat mempengaruhi proses pengolahan data, analisis data maupun hasil dari penelitian sehingga diharapkan untuk peneliti setelah ini lebih cermat dalam menyusun penelitian yang lebih kritis dengan keterbatasan-keterbatasan penelitian ini sebagai bahan pertimbangan. Adapun keterbatasan pada penelitian ini adalah sampel penelitian hanya perusahaan non keuangan yang tercatat dalam indeks Sri Kehati, serta beberapa variabel rasio keuangan yang digunakan sebagai variabel independen cenderung umum digunakan sehingga perlu diuji variabel rasio keuangan lainnya untuk membuktikan fungsi dari rasio keuangan yang lainnya secara lebih sistematis.

Berkaitan dengan simpulan serta keterbatasan penelitian yang telah disampaikan maka saran untuk penelitian selanjutnya adalah (1) memperdalam rumus perhitungan modal kerja bagi perusahaan keuangan/perbankan sehingga prediksi financial distress juga dapat diterapkan pada perusahaan keuangan/perbankan, (2) menggunakan rasio keuangan lainnya yang cenderung diabaikan agar fungsi rasio keuangan lainnya dapat diteliti lebih jauh (contoh: DER, OPM, dan lain sebagainya).

\section{DAFTAR PUSTAKA}

Abidin, Zainal. 2013. Pengaruh Rasio Keuangan Terhadap Perubahan Laba Pada Perusahaan yang Go Public di Bursa Efek Indonesia. Jurnal Ilmu \& Riset Akuntansi. 2 (5)

Akerlof, George A. 1970. The Market for 'Lemons': Quality Uncertainty and the Market Mechanism. Quarterly Journal of Economics (The MIT Press). 84 (3): 488-500.

Altman, Edward I. 2000. Predicting Financial, Distress of Companies : Revisiting The Zscore and Zeta ® Models. New York University: Stern School of Business.

Brigham F. Eugene dan Joel Houston. 2013. Dasar - Dasar Manajemen Keuangan: 
Assetials Of Financial Management. Jakarta: Salemba Empat.

Choirina, Putri Mutia. 2015. Analisis Faktor-Faktor Yang Mempengaruhi Probabilitas Financial Distress Perbankan Indonesia. Diponegoro Journal of Accounting. Vol. 4 No. 2, Hal 1-9.

Christananda, Claudia, dkk. 2017. Analisis Current Ratio dan Net Profit Margin untuk Memprediksi Kondisi Financial Distress Perusahaan (Studi pada Perusahaan Tekstil dan Garmen yang Terdaftar di Bursa Efek Indonesia Periode 2010-2015). eProceeding of Management. 4(1)

Haq, Syahidul, Muhammad Arfan, \& Dana Siswar. 2013. Analisa Rasio Keuangan dalam Memprediksi Financial Distress (Studi pada perusahaan yang terdaftar di Bursa Efek Indonesia). Jurnal Akuntansi. 2 (1)

Marwati, Dian. 2012. Analisis Rasio Keuangan untuk Memprediksi Kondisi Financial Distress pada Perusahaan Manufaktur yang Terdaftar di Bursa Efek Indonesia. Jurnal Fakultas Ekonomi dan Bisnis Universitas Dian Nuswantoro. Semarang: Universitas Dian Nuswantoro.

Mas'ud, Imam dan Reva Maymi Srengga. 2012. Analisis Rasio Keuangan Untuk Memprediksi Kondisi Financial Distress Perusahaan manufaktur Yang Terdaftar Di Bursa Efek Indonesia. Jurnal Akuntansi Universitas Jember. 3 (2): 139- 159.

Noviandri, Tio. 2014. Peranan Analisis Rasio Keuangan Dalam Memprediksi Kondisi Financial Distress. Jurnal iImu Manajemen. 2 (4): 1-11.

Nurcahyono, Ketut Sudharma. 2014. Analisis Rasio Keuangan Untuk Memprediksi Kondisi Financial Distress. Management Analysis Journal. Semarang: Universitas Negeri Semarang.

Prastowo, Dwi. 2011. Analisis Laporan Keuangan Konsep dan Aplikasi. Edisi Ketiga. Cetakan Pertama. Yogyakarta: UPP STIM YKPN.

Putra, Yogi Agung Permana. 2017. Analisis Rasio Keuangan untuk Memprediksi Kondisi Financial Distress Perusahaan Manufaktur yang Terdaftar di Bursa Efek Indonesia. E-Journal S1-Ak Universitas Pendidikan Ganesha. Singaraja: Universitas Pendidikan Ganesha.

Saleh, Amir dan Bambang Sudiyatno. 2013. Pengaruh Rasio Keuangan Untuk Memprediksi Probabilitas Kebangkrutan Pada Perusahaan Manufaktur yang Terdaftar di Bursa Efek Indonesia. Jurnal Dinamika Akuntansi Keuangan dan Perbankan. 2(1): 82-91.

Subramanyam, K.R. dan John J. Wild. 2010. Analisis Laporan Keuangan. Edisi Kesepuluh. New York: McGraw-Hill.

Sudana, I Made. 2011. Manajemen Keuangan Perusahaan Teori \& Praktik. Jakarta: Erlangga.

Widati, Listyorini Wahyu dan Bayu Adhi Pratama. 2014. Pengaruh Current Ratio, Debt to Equity Ratio, dan Return on Equity Untuk Memprediksi Kondisi Financial Distress. Jurnal Universitas Stikubank. Semarang: Universitas Stikubank.

Yudiawati, Rike dan Astiwi Indriani. 2016. Analisis Pengaruh Current Ratio, Debt to Total Asset Ratio, Total Asset Turnover, dan Sales Growth Ratio Terhadap Kondisi Financial Distress. Diponegoro Journal of Management. 5 (2, Hal): 1-13.

Zaki, E., Bah, R., dan Rao, A. 2011. Assesing Probabilities of Financial Distress of Banks in UAE. International Journal of Managerial Finance. 7 (3): 305.

"Merger Tiga Bank Pilihan Dilematis". [Surat Kabar]. Pikiran Rakyat. 6 Januari 2010, h.8. 